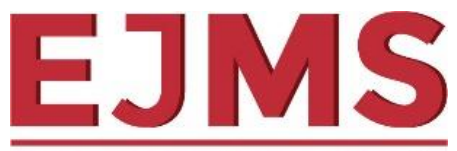

European Journal of Management Studies

\title{
LONGER WORKING LIVES AND AGE DIVERSITY: A NEW CHALLENGE FOR HRM
}

The European Journal of Management Studies is a publication of ISEG, Universidade de Lisboa. The mission of EJMS is to significantly influence the domain of management studies by publishing innovative research articles. EJMS aspires to provide a platform for thought leadership and outreach.

\section{Editors-in-Chief:}

\section{Gurpreet Dhillon, $\mathrm{PhD}$}

The University of North Carolina,

Greensboro, USA

Tiago Cardão-Pito, PhD

ISEG - Lisbon School of Economics and Management, Universidade de Lisboa,

Portugal

Managing Editor:

Mark Crathorne, MA

ISEG - Lisbon School of Economics and Management, Universidade de Lisboa,

Portugal

ISSN: 2 I83-4I72

DOI: 10.5455/EJMS.

Volume 24, Issue I

www.european-jms.com

Copyright (C) 2019 - ISEG, Universidade de Lisboa

\author{
Inês C. Sousa' and Sara Ramos ${ }^{2}$ \\ Instituto Universitário de Lisboa (ISCTE-IUL), 'BRU- \\ IUL, '2DINÂMIA'CET-IUL, Portugal
}

Orcid: $0000-0001-7438-819$

\begin{abstract}
An ageing workforce is one of the greatest challenges that organisations face today. Longer working lives result in greater age diversity that should be managed proactively by organisations in order to ensure that workers are able to stay active and productive until retirement age. We hypothesised that perceived work ability mediates the relationship between perceived age-diversity practices and preferred retirement age, and tested it in a sample of Portuguese workers $(n=290)$. The hypothesis was not supported. However, perceived age-diversity practices were identified as a predictor of perceived work ability, particularly for older workers ( $\geq 45$ years old). Also, perceived work ability predicted preferred retirement age, but not for older workers. The impact of these results on Human Resource Management (HRM) is discussed.
\end{abstract}

Key words: Age-diversity practices, work ability, preferred retirement age. 


\section{Introduction}

Populations across the world are ageing (United Nations, 2017). Governments and organisations are planning strategies to cope with growing dependency ratios, raising public and private pension costs, the increasing share of older workers, and the shortage of skills and workers (Burke and $\mathrm{Ng}$, 2006; Vickerstaff, Cox, and Keen, 2003).

To manage the ageing workforce, European Union have been implementing policies to increase the participation of older workers in the labour market, such as reducing incentives for early retirement and promoting the extension of the working life (i.e., postponing retirement age) (Flynn, 2010; Solem et al., 2016). However, the extension of workers' careers cannot only be encouraged by the discourse of social policies, but it requires an effective intervention by organisations. Thus, employers can have an important role in the retirement decisions of workers through the implementation of policies and practices that enable or constrain individual choices (e.g., employers' pension schemes, training and promotion opportunities) (Vickerstaff et al., 2003; Loretto and White, 2006).

Some studies have analysed the relationship between Human Resource (HR) practices and retirement (e.g., Herrbach, Mignonac, Vandenberghe, and Negrini, 2009; Saba and Guerin, 2005) but the findings are far from being conclusive. In fact, much is still unknown regarding the impact of organisational practices in encouraging workers to extend their working lives. This study contributes to the literature by addressing the research gap on how organisations can proactively encourage workers to desire to retire later. More specifically, we propose that organisations can develop HR practices that combat age barriers at work, promote age diversity in the workplace, and provide a work environment where each individual is able to reach his/her potential (Walker, 1999). These are called age-diversity practices, a construct that received little attention in the literature. Thus, the aim of the present study is to examine age-diversity practices and work ability as predictors of preferred retirement age. We propose that workers who recognise that there are age-diversity practices in their organisations and perceive good work ability will likely prefer to retire later. To our knowledge, no prior studies have examined the role of age-diversity practices in maintaining work ability and in influencing individuals' preference to retire later.

We expect that, by implementing age-diversity practices, organisations can increase workers' motivation to continue working, as these practices are a signal to workers that they are supported and valued, regardless of their age. Age-diversity practices can also be a mechanism to promote workers' well-being and health, which will increase workers' perception that they are able to perform their tasks. The term work ability refers to the balance between a worker's resources and the demands of work (Ilmarinen, 200I; Ilmarinen and von Bonsdorff, 2016). Individuals seek an optimal balance between resources and demands throughout their work life in order to continue working. On the contrary, poor work ability has been found to predict early retirement intentions and decisions (Sell et al., 2009; Tuomi, Huuhtanen, Nykyri, and Ilmarinen, 200 I; von Bonsdorff, Huuhtanen, Tuomi, and Seitsamo, 20I0). Retirement can be seen as giving 
up work as a dominant life sphere (Newman, Jeon, and Hulin, 20I3); so, impairments in work ability can lead to an early withdrawal from work.

In sum, organisations will play a crucial role in prolonging workers' careers by reducing their intentions to retire through motivating them and maintaining their work ability.

\section{Literature review}

\section{Ageing populations and the workforce}

Demographic ageing is a major challenge for contemporary societies. Since the second half of the 20th century, a new age structure has emerged, with an increasing percentage of older people and a decreasing proportion of young people; this trend is driven by declining birth rates, reduced child mortality rates and rising life expectancies (Chand and Tung, 2014; United Nations, 2017). The European continent is particularly aged and it continues ageing, and Portugal is no exception. Portugal is the fifth oldest country among the 28 European Union countries, with 14I elderly people (65 years old or more) per 100 young people (0-14 years old) (Statistics Portugal, $2014,2015)$. EUROSTAT demographic projections indicate that three out of ten residents in Portugal will be 65 years or older in 2050 .

One expected consequence of population ageing is the shrinkage of the labour force and the change in its age structure. In Portugal, projections indicated that the working-age population (15-64 years old) would decrease from 6.9 million in 2012 to 4.5 million in 2060 (Statistics Portugal, 2014). In opposition, the percentage of workers aged between 55 and 64 years old is expected to increase from 54.3 percent in 2013 to 68.7 percent in 2060 (European Commission, 2014). Also, in 2015, the index of renewal of the working-age population showed that, in potential terms, for every 100 persons exiting the labour market (55-64 years), there were only 84 entering it (20-29 years) (Statistics Portugal, 2015). These age projections influence the human resources available for organisations, but also have profound impacts on public policies. The threat of pension systems becoming unsustainable led to a mindset change at a political level in many western countries: Incentives for early retirement were replaced by increasing or abolishing the statutory retirement age (Hofäcker, 2015; Naegele and Krämer, 2002). As a result, individuals are now working longer than before, either because they want or they need to do so. For example, in Portugal, due to the need for reducing the expenditure in the Social Security sector, the normal age to access retirement varies according to the evolution of the average life expectancy at 65 years old (Decree-Law No. 167-E/2013). Currently, individuals must be 66 years and 5 months old (Ordinance No. 50/2019) and must have, at least, 15 years of contributions to the Social Security system to access the full retirement pension.

As a consequence of these demographic changes, not only is the workforce getting older, but it is also getting more diverse as younger and older workers are now working side-by-side. This 
increasing age diversity at work needs to be effectively managed (Rabl and Triana, 2014; Stone and Tetrick, 2013; Streb, Voelpel, and Leibold, 2008). Organisations will have to be proactive in their Human Resource Management (HRM), anticipating changes in their age structure and planning their human resources based on new age compositions (Pinto, Ramos, and Nunes, 20I4; Vendramin et al., 2012). For example, an organisation with an average age of 30 years old - much lower than the average age of $\mathbf{4 2 . 9}$ years for the Portuguese active population (Department of Statistics of Public Employment, 2016) - will face several medium-term challenges as the number of entries in the labour market is decreasing (e.g., recruit and retain older workers, recruit and hire international talent). Organisations will compete in attracting and recruiting new talent (Burke and $\mathrm{Ng}$, 2006), but they will also need to focus on retaining knowledge and skills that older workers possess (DeLong, 2004; Ng and Feldman, 2008).

One of the main concerns for organisations is to find HR practices that encourage older workers to remain motivated, engaged, productive, and healthy at work, contributing to successful organisational performance (Armstrong-Stassen and Schlosser, 20II; Schalk et al., 2010). However, HR practices cannot target only older workers. In order to extend workers' careers in a sustainable manner and contribute to individuals' successful ageing, organisational interventions should support workers throughout their life span (Truxillo, Cadiz, and Hammer, 20I5; Walker, 1999, 2005). Therefore, managers are called upon to design organisational policies and practices that allow the successful integration of workers of all ages (Truxillo et al., 20I5; Wegge et al., 20I2; Zaniboni, 20I5) - i.e., age-diversity practices.

\section{Age diversity and HR practices}

Managing age diversity is a complex and dynamic process for organisations as "it is impossible to impose standardisation or rules because of the very nature of diversity" (Riach, 2009, p. 332). Indeed, age-diverse workforces challenge the universality of HR practices. Previous research has shown that the worker's age is a determinant factor in designing organisational practices and policies (e.g., Kooij, Jansen, Dikkers, and De Lange, 2010; Kooij et al., 2013). Thus, in order for all workers to reach their potential of performance in a sustainable way, HRM should create, communicate and implement practices that support and promote the development of workers of all ages, that is, age-diversity practices (Kunze, Boehm, and Bruch, 2013; Truxillo, Cadiz, and Rineer, 2017). Implementing age-diversity practices implies that the organisation takes a proactive stance in recruiting, promoting and retaining workers of all ages, and also educating managers about leading age diversity workforces (Boehm, Kunze, and Bruch, 20I4; Walker, 2005). For example, if workers perceive that all workers, regardless of their age, have equal opportunities to be promoted, then they may perceive these as clear signals that the organisation is interested in retaining an age-diverse workforce. As proposed by Boehm and colleagues (20I4), HR practices should foster all workers' (a) knowledge and skills, (b) motivation and effort, and (c) opportunities to contribute to organisational goals. In this way, organisations interested in successfully managing an age-diverse workforce should ensure that all workers have the required 
knowledge and skills to perform their tasks effectively, and ensure that all workers have the motivation to contribute to organisational goals.

These practices should be flexible, inclusive and non-discriminatory, and take into account not only the interindividual variability in workers' skills, preferences and goals (Walker, 1999), but also intraindividual differences, recognising that individuals, their needs and their interests may change over time. This means that specific HR practices may not be of value to all workers in the same age group, and also, one worker may not value the same practices during his/her entire career. In sum, age-diversity practices consider the needs, interests and values of all workers, and not exclusively those of certain age groups. Moreover, age-diversity practices can contribute to increase the perception of justice among colleagues by avoiding favouring some age groups over others and attenuating negative age stereotypes within organisations (Boehm and Dwertmann, 2015; Posthuma and Campion, 2009).

There is a great difference between the actual HR practices that are implemented by managers and the way they are perceived by workers (Khilji and Wang, 2006). Den Hartog, Boselie and Paauwe (2004) argue that HR practices are interpreted by workers as signals of the organisations' intentions towards them. Following this reasoning, it is important to consider workers' perceptions when designing HR practices. Workers' perceptions about age-diversity practices are, therefore, the focus of the present study. Perceived age-diversity practices refer to the degree to which individuals perceive that workers of all ages receive non-discriminatory treatment in terms of organisational practices, policies and procedures (Boehm et al., 20I4; Kunze et al., 20I3; Walker, 1999). Age-diversity practices can be seen as a mechanism for workers to extend their careers: If individuals perceive that there are HR practices for workers of all ages, then they will demonstrate a better work ability and less preferences to retire earlier.

\section{Perceived work ability}

Demographic ageing and the governments' increasing of the age to access retirement (e.g., Portugal, Germany, Sweden) triggered the growing interest of researchers in work ability (e.g., Ilmarinen, 200I; Lindberg, Josephson, Alfredsson, and Vingård, 2006; Tuomi et al., 200I), consistently identifying it as a predictor of labour market exit (Sell et al., 2009; von Bonsdorff et al., 20l I). Work ability is a product of the individual and his work context: To be able to continue working in the short, medium and long term, individuals have to balance their personal resources - physical and mental resources - with work requirements (IImarinen, 200I; Ilmarinen and Tuomi, 1992). Work ability has been measured through the Work Ability Index (WAl; Tuomi, Ilmarinen, Jahkola, Katajarinne, and Tulkki, 1998); but psychometric research has identified two dimensions: one objective and one subjective (Radkiewicz and Widerszal-Bazyl, 2005). Thus, more recently, McGonagle, Fisher, Barnes-Farrell, and Grosch (20I5) proposed the concept of perceived work ability as an individual's self-assessment about the degree to which he or she possesses personal resources to meet work demands. Having work ability means having the 
functional capacities (mental, physical and social resources), and individual health, competence, attitudes and values to successfully manage and perform the work tasks (llmarinen and von Bonsdorff, 2016; Tengland, 20II). On the other hand, the absence of sufficient resources may lead to decreasing levels of psychological or physical well-being (McGonagle et al., 20I5).

To find a balance, personal resources and work demands need to be continuously combined as they are continuously changing (Ilmarinen, 2009). Personal resources are expected to change with age. From a life-span development perspective, ageing is a multidimensional process that encompasses changes in body functioning over time and has positive and negative implications (Kanfer and Ackerman, 2004; Zacher, 2015). Ageing is related with declines in certain physical abilities (e.g., reduced visual acuity, longer recovery time from stressors) and cognitive functions (e.g., slower processing speed, decline in working memory) (Kanfer and Ackerman, 2004; Truxillo et al., 2015). However, positive age-related changes can occur, such as gains in crystallized intelligence (Salthouse, 20I2) and affective well-being (Charles and Luong, 20I3). In the light of selection, optimization, and compensation (SOC) theory, workers have a remarkable adaptive capacity to deal with age-related changes throughout the life course by reducing the impact of age-related losses while taking advantage of age-related gains (Baltes and Baltes, 1990; Freund and Baltes, 1998).

Work demands also change. Globalization, mobility, rapid technological change, and higher customer demands for sustainable products and services are impacting and changing what it means to work, and to be a worker (Burke and Ng, 2006; Ilmarinen, 2009; Tuomi, Vanhala, Nykyri, and Janhonen, 2004). Since the world of work evolves at a constant rate and ageing cannot be avoided, individuals have to protect their physical and mental well-being using selection, optimization and compensation strategies (Young, Baltes, and Pratt, 2007). For example, an older worker may compensate for a loss in physical abilities by taking additional breaks or asking colleagues for help.

Despite that, organisations also have an important role in promoting work ability. According to Ilmarinen and Rantanen (1999), work ability promotion consists of making adjustments in the physical (e.g., ergonomic aspects) and psychosocial (e.g., leader and team support) work environment, fostering health and lifestyle, and updating professional skills. Therefore, agediversity practices can be a key to promote work ability.

Ultimately, perceived work ability may influence workers' decisions about their future - both in a specific organisation or in the labour market. In this study, our focus is on the intention to exit the labour market through retirement, proposing that workers who perceive poor work ability will likely prefer to retire earlier. 


\section{Preferred retirement age}

Conceptualized as the most significant transition in later adulthood, retirement has been defined as "the exit from an organisational position or career path of considerable duration, taken by individuals after middle age, and taken with the intention of reduced psychological commitment to work thereafter" (Feldman, 1994, p. 287). It is a complex decision-making process that unfolds over time, where individuals reflect, plan and decide when and how they will enrol in retirement (Beehr, 1986; Moen, 2012; Topa, Moriano, Depolo, Alcover, and Morales, 2009). In light of the cost-benefit framework, individuals opt for retirement when the benefits of retirement (e.g., decreased job-related stress, time for leisure or family activities) exceed the costs of retirement (e.g., loss of contacts with co-workers, loss of work identity) (Feldman and Beehr, 20II; Szinovacz and Davey, 2005). Research has shown that cost-benefit considerations in retirement decisions are related with a range of individual (e.g., financial situation, health, family support) and organisational (e.g., job demands, stress, recognition) aspects (Beehr, 20l4; Blekesaune and Solem, 2005; Carr et al., 2016; Kim and Feldman, 1998; Shultz and Wang, 2007; Szinovacz, DeViney, and Davey, 200I). Some of these aspects are push factors, that is, negative considerations that induce workers to retire, such as poor health or poor job satisfaction; whereas others are pull factors (i.e., positive considerations that attract workers toward retirement), such as financial incentives or opportunity to spend more time with family (Beehr, Glazer, Nielson, and Farmer, 2000; Carstensen, Fung, and Charles, 2003; De Preter, Van Looy, and Mortelmans, 2013; Oakman and Wells, 2013; Shultz, Morton, and Weckerle, 1998). Literature indicates that individuals may opt for retirement as a result of push factors, pull factors, or a combination of both (Barnes-Farrell, 2003; De Preter et al., 20I3; Fisher, Chaffe, and Sonnega, 2016).

However, despite the individual's considerations, reflections and plans, the actual retirement age may differ from preferred retirement age due to the interference of factors that had not been contemplated initially (van Solinge and Henkens, 2009). Thus, as this study is oriented for the working population - workers of different ages and in different career phases - the variable under analysis will be workers' preferred retirement age. The preferred retirement age encompasses workers' preferences and desires concerning the retirement timing (Hess, 2017). It is an intrinsic desire strongly influenced by institutional (e.g., regulation of the public pension system, availability of private pension plans), organisational (e.g., age-related stereotypes, workforce cutbacks or layoffs) and individual (e.g., leisure orientation, job attitudes) characteristics (Beehr et al., 2000; Han and Moen, 1999; Zappalà, Depolo, Fraccaroli, Guglielmi, and Sarchielli, 2008). Hence, some factors that explain the preferred retirement age are under the control of organisations. Thus, we examine a particular dimension of the workplace reality age-diversity practices - as an important predictor of preferred retirement age. 


\section{Proposed model}

Based on previous research, we propose that preferred retirement age can be explained by the interaction between perceived age-diversity practices and perceived work ability. As ageing is a natural process that involves a progressive deterioration of some important physiological capacities, older workers are, in general, more susceptible to health problems (Hansson, DeKoekkoek, Neece, and Patterson, 1997). Additionally, the work environment can aggravate or accelerate an individual's physical and psychological distress (Dal Bianco, Trevisan, and Weber, 2015; Teiger, 1989). For this reason, it is necessary that organisations adopt strategies and interventions that accommodate major changes in work-related capacities and skills, promoting work ability (Ilmarinen, 200I; Truxillo et al., 20I5). In this sense, age-diversity practices can be an organisational strategy to improve perceived work ability. In turn, and applying cost-benefit theory to preferred retirement age (Feldman and Beehr, 20I I), a good work ability may lead individuals to feel that the benefits of working outweigh the benefits of retiring, opting to delay retirement timing. In short, individuals who perceive the existence of age-diversity practices are expected to show better perceived work ability, which, in turn, will lead them to desire to retire later. Thus, we propose a mediation model with the following hypothesis:

$\mathrm{H}$ : Perceived work ability mediates the relationship between perceived age-diversity practices and preferred retirement age.

\section{Methods}

\section{Participants}

The sample consisted of 290 Portuguese workers, aged between 19 and 67 years old $(M=37.80$, $S D=13.08$ ). From the 290 participants, 58.5 percent were female. The educational level of participants varied: the majority completed higher education (5I.2\%), 33.6 percent reported having completed high school, 9.3 percent completed the $9^{\text {th }}$ grade, 4.8 percent the $6^{\text {th }}$ grade, and finally, only I percent reported having completed the $4^{\text {th }}$ grade. Among the 290 participants, 54.7 percent reported not having dependents, and the average number of dependents was 0.72 (SD = 0.93). Twenty-eight percent of participants showed an organisational tenure of one to five years, and 17.4 percent were in the organisation for more than 25 years. Also, 24.2 percent of the participants were in the labour market for one to five years, and 20.4 percent worked for more than 30 years. Most of the participants worked in the private sector $(67.7 \%)$ - mainly in sales, and health and social support sectors (15.4\%), hospitality and tourism (10.8\%), and banking and financial services (10.5\%). 


\section{Procedure}

The present study was conducted in Portugal. All data were collected through a paper questionnaire. The average time it took participants to complete the questionnaire was approximately 15 minutes. Data were collected by a group of undergraduate and master students from ISCTE - University Institute of Lisbon, through their personal contacts and in their workplaces and internship places. Students participated in this research as part of their academic training and got credits to their evaluation.

\section{Measures}

The following measures were used in this study for collecting required data from the participants.

Perceived age-diversity practices. This scale measures the extent to which workers perceive a nondiscriminatory treatment of workers of all ages regarding organisational practices, policies and procedures (adapted from Boehm et al., 2014). Participants indicated on a 6-point scale their agreement ( 1 - Strongly Disagree to 6 - Strongly Agree) with seven statements (e.g., Employees are developed (i.e., training) and advanced without regard to the age of the individual.). The scale revealed a good internal consistency $(\alpha=0.876)$.

Perceived work ability. Perceived work ability refers to individuals' perception of their ability to continue working considering work demands and their personal resources (McGonagle et al., 2015). It was measured through four questions regarding both physical and mental demands of the work, and participants answered on a scale from I (Very Poor) to 5 (Very Good) (e.g., How do you rate your current work ability to meet physical demands?) (adapted from Tuomi et al., 1998). Responses to the 4-item scale were analysed using a principal component analysis (PCA). We conducted the Bartlett test of sphericity, and the Kaiser-Meyer-Olkin (KMO) measure of sampling adequacy to determine the appropriateness of the analysis. The KMO sampling adequacy was 0.607 and the $p$ value for the Bartlett's test was less than $0.00 \mathrm{I}$, indicating the model was appropriate for analysis. Examination of eigenvalues and the scree plot revealed a single factor, accounting for 70 percent (70\%) accumulated variance. This scale shows good internal consistency $(\alpha=0.856)$.

Preferred retirement age. Preferred retirement age expresses an individual wish, desire, or preference concerning retirement timing, and it was operationalized through one question expressed as "At what age would you like to retire?" (Zappalà et al., 2008). Participants indicated the age (in years) they would like to retire.

\section{Results}

Data were analysed using version 23 of the Statistical Package for Social Sciences (SPSS). Means and standard deviations for seven items of perceived age-diversity practices are shown in Table I. 
Item

M

$S D$

Employees are developed (i.e., training) and advanced without regard to the age of the individual.

$3.73 \quad 1.617$

Managers in my organisation demonstrate through their actions that they want to hire and retain an age-diverse workforce.

I feel that my immediate supervisor does a good job managing people of different ages.

It is easy for people from diverse age groups to fit in and be accepted.

All workers have the same opportunities to get an adequate evaluation, regardless their age

The work is adjusted to workers' needs over time.

Experience, skills and knowledge of workers are recognized, irrespective of their age.

Note. Items were answered on a Likert scale from I (Strongly Disagree) to 6 (Strongly Agree).

\section{Table I: Mean and Standard Deviation of Perceived Age-diversity Practices}

On average, participants' answers are close to the two central points of the scale ( 3 and 4$)$ which shows that, in general, organisations can improve their age-diversity practices. Participants agreed that people from diverse age groups fit in and are accepted in their organisation $(M=4.29, S D=$ I.466), being this, on average, the most common practice. On the contrary, participants did not consistently agree on the existence of a work adjustment to workers' needs over time $(M=3.45$, $S D=1.474)$. Regarding perceived work ability, means and standard deviations for four questions are presented in Table 2.

Question

How do you rate your current work ability to meet physical demands?

How do you rate your current work ability to meet psychological demands?

How do you rate your future work ability to meet physical demands within two years?

How do you rate your future work ability to meet psychological demands within two years?
M

$4.14 \quad 0.907$

$3.99 \quad 0.823$

$3.89 \quad 0.989$

$3.79 \quad 1.015$

Note. Items were answered on a Likert scale from I (Very Poor) to 5 (Very good).

Table 2: Mean and Standard Deviation of Perceived Work Ability 
Findings show that participants evaluated, on average, their current work ability to meet physical demands as good $(M=4 . I 4, S D=0.907)$. To meet psychological demands, this self-evaluation was slightly lower $(M=3.99, S D=0.823)$. Participants indicated expecting a decrease in their future work ability for meeting both physical and psychological demands.

Participants indicated that, on average, they would like to retire at 59 years old $(M=59.39, S D=$ 6.296). Results indicated that there is a positive significant - although very small - correlation between age and preferred retirement age $(r=0.13, p<0.05)$, meaning that as people grow older, their preferred retirement age also increases.

To analyse the mediation hypothesis, we used SPSS to create 5,000 bootstrap samples and used 95\% confidence intervals $(\mathrm{Cl})$ (Preacher and Hayes, 2008). Linear regression analysis was used to examine the hypothesis that perceived work ability mediates the effect of perceived age-diversity practices on preferred retirement age. Results indicated that perceived age-diversity practices were not a significant predictor of retirement intention $[b=-0.202 ; S D=0.346 ; p=0.560]$. Thus, the hypothesis was not supported.

Although the mediation was not supported, we proceeded testing the model separately through two simple linear regressions: First, we tested the influence of perceived age-diversity practices on perceived work ability; then, we examined the effect of perceived work ability on preferred retirement age. Findings showed that perceived age-diversity practices are a significant predictor of perceived work ability $\left(F(I, 279)=38.486, p<0.00 I ; R^{2}=0.12 I\right)$. For every one unit increase in perceived age-diversity practices, perceived work ability improved by $0.23 \mathrm{I}$ points; this means that the more positive the workers' perception of age-diversity practices, the better their perceived work ability. Results also showed that perceived work ability significantly predicts preferred retirement age $\left(F(I, 277)=4.348, p=0.038 ; R^{2}=0.015\right)$. For every one unit increase in perceived work ability, the ideal age for retirement increased one year, meaning that the better the perceived work ability, the later workers indicated they would like to retire.

Additionally, we compared the effect of perceived age-diversity practices on perceived work ability between younger workers ( $\leq 30$ years) and older workers ( $\geq 45$ years). According to previous research, we defined the younger worker as being age 30 years or under and the older worker as being age 45 years or over (Finegold, Mohrman, and Spreitzer, 2002; Ilmarinen, 200I). Results showed that this relationship is significant for both younger workers $(F(I, I I 5)=6.048, p$ $\left.=0.015 ; R^{2}=0.050\right)$ and older workers $\left(F(I, 105)=18.272, p<0.001 ; R^{2}=0.148\right)$, but more important for the older $(B=0.263)$ than for the younger $(B=0.145)$. Then, we compared the same two age groups regarding the effect of perceived work ability on preferred retirement age. Findings show that this relationship is marginally significant for younger workers $(F(I, I I 6)=$ 4.055, $p=0.046 ; R^{2}=0.034$ ) but not significant for older workers $(F(I, I 03)=1.803$, n.s. $)$. 


\section{Discussion}

The present study aimed to analyse the influence of perceived age-diversity practices on preferred retirement age through the mediation of perceived work ability in a sample of Portuguese workers. Empirical findings did not support the mediation hypothesis. However, although perceived age-diversity practices did not show a direct relationship with preferred retirement age, it was an important predictor of perceived work ability. This finding is consistent with the literature and it illustrates the important role that organisations can have in promoting sustainable careers by creating practices that fit the needs and preferences of workers of all ages (Vendramin et al., 2012). Strategic HRM in organisations should focus not only on the recruitment and selection of an age-diverse workforce, but also on its retention, focusing on training, promoting and recognising the best talents. In fact, age-diversity practices can possibly be seen as accommodation, maintenance and development practices that enable workers to continue contributing to organisational performance across their entire life span. Age-diversity practices are accommodation practices once they propose workplace measures that accommodate lower levels of functioning (Kooij, Jansen, Dikkers, and De Lange, 20I4; van Dalen, Henkens, and Wang, 2015). These are also maintenance practices as these measures support individual workers to maintain their current levels of functioning, or to return to previous levels, in the face of age-related changes (Bal, Kooij, and De Jong, 20I3; Kooij et al., 20l4;). For example, by adjusting the work to workers' needs over time (e.g., decreases in workload, exemption from overtime or irregular shifts, ergonomic adjustments), these practices can prompt a better health and functional capacity in general, aspects that can preserve work ability. As development practices, age-diversity practices present workplace measures that aim to increase the ability, motivation and opportunity to perform well (Bal et al., 2013; van Dalen et al., 20I5). Regardless of the worker's age, the organisational investment in knowledge can help individuals to achieve higher levels of functioning (Kooij et al., 20I4). For example, by developing, promoting and recognizing workers' experience, skills and knowledge (e.g., training, internal promotion, job mobility), these practices allow the deepening of the professional knowledge required to execute the job, another important aspect of work ability.

The influence of perceived age-diversity practices on perceived work ability has proved to be particularly important for older workers, which may be due to the fact that older workers are frequently the target of age discrimination in the workplace (e.g., Finkelstein, Burke, and Raju, 1995; Posthuma and Campion, 2009). Unlike other types of discrimination (e.g., gender, racial), age discrimination is likely to be subtle and based on age stereotypes that are widespread in organisations. Negative age stereotypes (e.g., older workers are less motivated and less able to learn new skills) are frequently accepted by managers and employers, either explicitly or implicitly, resulting in the underutilization of older workers (Bal, Reiss, Rudolph, and Baltes, 20I I; Posthuma and Campion, 2009). In fact, older workers are often not included in HRM practices as seen, for example, in having less access to training and development opportunities than younger workers (Armstrong-Stassen and Ursel, 2009). When workers do not see their skills up- 
to-date, they feel less able to perform their tasks and appropriately meet job demands. Therefore, age-diversity practices can be viewed by older workers as a sign that the organisation cares about their well-being, needs and preferences, invests in their professional development and supports their career. Hence, age-diversity practices are supportive HR practices that sustain older workers' ability and motivation and offer them opportunities to remain at work (Kooij et al., 20I4).

Overall, perceived work ability proved to be an important predictor of retirement intention, as shown by previous research (e.g., Feldt, Hyvönen, Mäkikangas, Kinnunen, and Kokko, 2009; von Bonsdorff et al., 2010). When workers feel their capabilities at work no longer match the physical or mental requirements of their jobs, they will likely desire to retire early. This relationship can be understood in the light of the SOC (Baltes and Baltes, 1990) and Conservation of Resources (COR) (Hobfoll, 1989) theories. The actual loss or the threat of losing personal resources (e.g., physical ability, key skills) - due to a declining work ability - requires individuals to employ one of two strategies: a realignment of available resources to compensate for those that are failing, or a re-evaluation of the resources lost or likely to be lost (Freund and Baltes, 1998; Hobfoll, Halbesleben, Neveu, and Westman, 2018). Such re-evaluation of resources may be accomplished cognitively, by lowering the worker's organizational commitment, or behaviourally, by leaving the labour market via retirement (Bayl-Smith and Griffin, 20I4). Thus, in this study, lower levels of work ability (i.e., losing resources) lead workers to re-evaluate their lost resources and to desire leaving the workforce earlier.

However, for older workers (i.e., aged 45 years or over) the influence of perceived work ability on preferred retirement age was not significant. This finding is not consistent with previous research showing that older workers with low levels of work ability are more likely to withdrawal from the labour force through early-gradual retirement (Boissonneault and de Beer, 2018; Tuomi et al., 200I). However, this particular result concurs with the idea that, although workers may experience poor health and low work ability, some factors (e.g., financial insecurity, lack of alternative sources of income) may keep older workers longer in the labour market (Oksanen and Virtanen, 20I2). For example, workers should be eligible to receive retirement benefits (e.g., retirement pension) to replace income, otherwise they will depend on earlier savings to finance consumption (Bingley and Martinello, 2013). Also, the decision-making process of retirement does not occur in a social vacuum. Social groups (e.g., co-workers, friends) can also influence individuals' decision about when to retire. For example, workers seek advice and support from co-workers when they begin to think about retirement, and consider their opinions in their decision-making process (Potočnik, Tordera, and Peiró, 2009).

The transition to retirement is a multidimensional, complex and dynamic process, involving the weighting of different factors (e.g., financial situation, legal requirements, social support) at different stages (Fisher et al., 2016; Topa, Depolo, and Alcover, 2018). There is also a temporal view in the retirement process: as individual's age, they enrol in retirement preparation, that is to 
say, planning and taking actions to ensure that they will have a satisfying lifestyle as retirees (Adams and Rau, 20II). Older workers are chronologically closer to the retirement age and previous research has shown that retirement-oriented activities increase with years of proximity to retirement (Ekerdt, Kosloski, and DeViney, 2000; Evans, Ekerdt, and Bosse, 1985). Therefore, older workers are more likely to be aware of the many different factors involved in the retirement decision-making process. They also may have already considered the ideal retirement timing and the desirable conditions to do so. Therefore, in this study, older workers may have weighted other important factors when indicating their preferred retirement age, concluding that work ability is not the main predictor of this decision.

To sum up, this study contributes to the HRM literature by demonstrating that age-diversity practices, which combine accommodation, maintenance and development HR practices, relate to better work ability not only for older workers, but for all workers. Therefore, organisations are called to implement age-diversity practices (e.g., recruitment and selection, training, health and safety at work) to preserve workers' work ability. These practices will likely have a similar effect to other intervention programmes that are effective to increase work ability and reduce early retirement, contributing to the retention of valuable human resources (Cloostermans, Bekkers, Uiters, and Proper, 20I5; de Boer, van Beek, Durinck, Verbeek, and van Dijk, 2004).

Also, this study contributes to the retirement literature by demonstrating that perceived work ability predicts preferred retirement age for younger workers. Although work ability is usually studied in older workers (e.g., Tuomi et al., 200I), younger workers can also benefit from organisational interventions to promote excellent work ability (Lindberg et al., 2006). This investigation draws attention to the importance of organisations take a proactive approach in managing the work ability of their workers, throughout their working life. This study also seems to suggest that work ability is not the most important predictor of preferred retirement age for older workers. The complex relationship between health and retirement (Oksanen and Virtanen, 2012) probably also applies to work ability and retirement, meaning that work ability interacts with other aspects in predicting individuals' desire to retire. Despite the reduced work ability, an opportunity to retire, other aspects constrain the retirement behaviour, keeping employees longer in employment.

\section{Limitations and Future Research}

Retirement has been studied since the beginning of the $20^{\text {th }}$ century, but it became a prominent research topic in the last 50 years. As a result, there is a broad body of literature about retirement antecedents (e.g., individual, job, organisational, socioeconomic) and outcomes (e.g., postretirement health, leisure activities). The aim of this study was to examine the influence of organisational-related factors (i.e., age-diversity practices) in the preferred retirement age. As other antecedents were not included in the model, future research should analyse the role of age-diversity practices combined with individual attributes and job factors in retirement 
intentions. In addition, in this study, we used preferred retirement age as a proxy for retirement behaviour. Perhaps future research could operationalize retirement intentions using other indicators such as expected retirement age, preference for early or late retirement or the age considering retirement for the first time (Potočnik et al., 2009; Zappalà et al., 2008).

This study has some limitations that should be taken into account when interpreting the findings. The first limitation is the convenience sample which is not representative of Portuguese workers. A convenience sample does not allow the generalisation of findings to the active population in Portugal, since there may be under-representation or over-representation of specific groups in the sample. However, a more traditional paper-and-pencil questionnaire and the data collection procedure allowed access to participants who, otherwise (e.g., online questionnaire), might not be available. As this is a cross-sectional study in which all measures were collected in a single moment, it is not possible to establish a causal relationship between the variables under analysis. Longitudinal studies are required to examine the relationship between organisational practices and work ability over time, as well as the influence of these variables on retirement intentions. By following workers over time, researchers could identify and distinguish different age-related effects (e.g., chronological age, career phase, tenure in the organisation) in the model under analysis. Finally, in this study, we tested a mediation model using linear regression analysis. However, our results suggested that future studies should use nonlinear models to examine the influence of age-diversity practices and work ability on preferred retirement age.

\section{Conclusions}

Organisations will inevitably be confronted with several challenges related to an ageing workforce. To increase older workers' employability and to ensure sustainable working careers for all workers, managers will have to design HRM practices that consider workers' age. We proposed a mediation model where perceived age-diversity practices positively influence perceived work ability that, in turn, would influence the workers' desire to retire later. The mediation hypothesis has not been supported. However, results allow us to conclude that agediversity practices and work ability are part of a more complex model that explains preferred retirement age. Retirement is, as previous research has shown, a dynamic process as the weight of the factors involved in the decision-making process changes over time. Thus, it is fundamental to understand the influence of work-related factors, such as age-diversity practices, in processes that explain retirement intentions like work ability. In this way, organisations can ensure that workers of all ages have access to more sustainable careers and can work longer, if they desire. 


\section{References}

Adams, G. A., \& Rau, B. L. (20I I). Putting off tomorrow to do what you want today: Planning for retirement. American Psychologist, 66(3), 180-192. http://dx.doi.org/ 10.1037/a0022 I 3 I

Armstrong-Stassen, M., \& Schlosser, F. (201I). Perceived organizational membership and the retention of older workers. Journal of Organizational Behavior, 32(2), 319-344. https://doi.org// 0.1002/job.647

Armstrong-Stassen, M., \& Ursel, N. D. (2009). Perceived organizational support, career satisfaction, and the retention of older workers. Journal of Occupational and Organizational Psychology, 82(I), 20I-220. https://doi.org/I0.1348/0963 I7908X288838

Bal, P. M., Kooij, D. T., \& De Jong, S. B. (20I3). How do developmental and accommodative HRM enhance employee engagement and commitment? The role of psychological contract and SOC strategies. Journal of Management Studies, 50(4), 545-572. https://doi.org/ I 0. I I I I/joms. I 2028

Bal, A. C., Reiss, A. E. B., Rudolph, C. W., \& Baltes, B. B. (20I I). Examining positive and negative perceptions of older workers: A meta-analysis. Journals of Gerontology Series B: Psychological Sciences and Social Sciences, 66(6), 687-698. https://doi.org/ I 0.1093/geronb/gbr056

Baltes, P. B., \& Baltes, M. M. (1990). Psychological perspectives on successful aging: The model of selective optimization with compensation. In P. B. Baltes \& M. M. Baltes (Eds.), Successful aging: Perspectives from the behavioral sciences (pp. I-34). New York: Cambridge University Press.

Barnes-Farrell, J. L. (2003). Beyond health and wealth: Attitudinal and other influences on retirement decision-making. In G. A. Adams \& T. A. Beehr (Eds.), Retirement: Reasons, processes, and results (pp. 159-187). New York: Springer Publishing Company.

Bayl-Smith, P. H., \& Griffin, B. (20/4). Age discrimination in the workplace: Identifying as a late-career worker and its relationship with engagement and intended retirement age. Journal of Applied Social Psychology, 44(9), 588-599. https://doi.org/ I 0.I I I I/jasp. 1225 I

Beehr, T. A. (1986). The process of retirement: A review and recommendations for future investigation. Personnel Psychology, 39(I), 3 I-55. https://doi.org/ I0. I I I I/j. I 744-6570.1986.tb00573

Beehr, T. A. (2014). To retire or not to retire: That is not the question. Journal of Organizational Behavior, 35(8), 1093-I I08. https://doi.org/10.1002/job.1965

Beehr, T. A., Glazer, S., Nielson, N. L., \& Farmer, S. J. (2000). Work and nonwork predictors of employees' retirement ages. Journal of Vocational Behavior, 57(2), 206-225. https://doi.org//0.1006/jvbe.1999.1736

Bingley, P., \& Martinello, A. (20I3). Mental retirement and schooling. European Economic Review, 63, 292-298. https://doi.org/10.1016/j.euroecorev.2013.01.004 
Blekesaune, M., \& Solem, P. E. (2005). Working conditions and early retirement: A prospective study of retirement behavior. Research on Aging, 27(I), 3-30. https://doi.org/I0.1 I77/016402750427/438

Boehm, S. A., \& Dwertmann, D. J. (2015). Forging a single-edged sword: Facilitating positive age and disability diversity effects in the workplace through leadership, positive climates, and HR practices. Work, Aging and Retirement, I(I), 4I-63. https://doi.org//0.1093/workar/wau008

Boehm, S. A., Kunze, F., \& Bruch, H. (20I4). Spotlight on age-diversity climate: The impact of ageinclusive HR practices on firm-level outcomes. Personnel Psychology, 67(3), 667-704. https://doi.org/I0.1 I I I/peps. 12047

Boissonneault, M., \& de Beer, J. (2018). Work ability trajectories and retirement pathways: A longitudinal analysis of older American workers. Journal of Occupational and Environmental Medicine, 60(7), e343-e348. https://doi.org//0.1097/JOM.000000000000I353

Burke, R. J., \& Ng, E. (2006). The changing nature of work and organizations: Implications for human resource management. Human Resource Management Review, I6(2), 86-94. https://doi.org//0.1016/j.hrmr.2006.03.006

Carr, E., Hagger-Johnson, G., Head, J., Shelton, N., Stafford, M., Stansfeld, S., \& Zaninotto, P. (2016). Working conditions as predictors of retirement intentions and exit from paid employment: A 10-year follow-up of the English Longitudinal Study of Ageing. European Journal of Ageing, I3(I), 39-48. https://doi.org/I0.1007/s 10433-0I5-0357-9

Carstensen, L. L., Fung, H. H., \& Charles, S. T. (2003). Socioemotional selectivity theory and the regulation of emotion in the second half of life. Motivation and Emotion, 27(2), 103-123. https://doi.org/I0.1023/A:I024569803230

Chand, M., \& Tung, R. L. (20I4). The aging of the world's population and its effects on global business. The Academy of Management Perspectives, 28(4), 409-429. https://doi.org// 0.5465/amp.2012.0070

Charles, S. T., \& Luong, G. (2013). Emotional experience across adulthood: The theoretical model of strength and vulnerability integration. Current Directions in Psychological Science, 22(6), 443-448. https://doi.org//0.1 177/096372/4/34970/3

Cloostermans, L., Bekkers, M. B., Uiters, E., \& Proper, K. I. (2015). The effectiveness of interventions for ageing workers on (early) retirement, work ability and productivity: A systematic review. International Archives of Occupational and Environmental Health, 88(5), 52 I-532. https://doi.org// 0.1007/s00420-014-0969-y

Dal Bianco, C., Trevisan, E., \& Weber, G. (2015). "I want to break free”. The role of working conditions on retirement expectations and decisions. European Journal of Ageing, 12(I), 17-28. https://doi.org//0.1007/s10433-014-0326-8 
de Boer, A. G. E. M., van Beek, J.-C., Durinck, J., Verbeek, J. H. A. M., \& van Dijk, F. J. H. (2004). An occupational health intervention programme for workers at risk for early retirement; a randomised controlled trial. Occupational and Environmental Medicine, 6I(II), 924-929. http://dx.doi.org/ I0.1 I36/oem.2003.009746

De Preter, H., Van Looy, D., \& Mortelmans, D. (2013). Individual and institutional push and pull factors as predictors of retirement timing in Europe: A multilevel analysis. Journal of Aging Studies, 27(4), 299-307. https://doi.org/10.1016/j.jaging.2013.06.003

DeLong, D.W. (2004). Lost knowledge: Confronting the threat of an aging workforce. Oxford: Oxford University Press.

Den Hartog, D. N., Boselie, P., \& Paauwe, J. (2004). Performance management: A model and research agenda. Applied Psychology, 53(4), 556-569. https://doi.org/I0.1 III/j.I4640597.2004.00188.x

Department of Statistics of Public Employment. (2016). Boletim estatístico do emprego público [Public employment statistics bulletin]. Lisbon: Directorate-General for Administration and Public Employment.

Ekerdt, D. J., Kosloski, K., \& DeViney, S. (2000). The normative anticipation of retirement by older workers. Research on Aging, 22(I), 3-22. https://doi.org/ I0. I I 77/0 I6402750022 I 00 I

European Commission. (2014). The 2015 ageing report: Underlying assumptions and projection methodologies. Luxembourg: Publications Office of the European Union. https://doi.org// 0.2765/76255

Evans, L., Ekerdt, D. J., \& Bosse, R. (1985). Proximity to retirement and anticipatory involvement: Findings from the normative aging study. Journal of Gerontology, 40(3), 368-374. https://doi.org// 0.1093/geronj/40.3.368

Feldman, D. C. (1994). The decision to retire early: A review and conceptualization. Academy of Management Review, 19(2), 285-3I I. https://doi.org/I0.5465/AMR.1994.94I021075 I

Feldman, D. C., \& Beehr, T. A. (20II). A three-phase model of retirement decision making. American Psychologist, 66(3), 193-203. https://doi.org/10.1037/a0022153

Feldt, T., Hyvönen, K., Mäkikangas, A., Kinnunen, U., \& Kokko, K. (2009). Development trajectories of Finnish managers' work ability over a 10-year follow-up period. Scandinavian Journal of Work, Environment \& Health, 35(I), 37-47. https://doi.org/I0.527//sjweh. I30I

Finegold, D., Mohrman, S., \& Spreitzer, G. M. (2002). Age effects on the predictors of technical workers' commitment and willingness to turnover. Journal of Organizational Behavior, 23(5), 655674. https://doi.org/10.1002/job.159 
Finkelstein, L. M., Burke, M. J., \& Raju, M. S. (1995). Age discrimination in simulated employment contexts: An integrative analysis. Journal of Applied Psychology, 80(6), 652-663. https://doi.org//0.1037/0021-9010.80.6.652

Fisher, G. G., Chaffee, D. S., \& Sonnega, A. (2016). Retirement timing: A review and recommendations for future research. Work, Aging and Retirement, 2(2), 230-26I. https://doi.org//0.1093/workar/waw00I

Flynn, M. (2010). Who would delay retirement? Typologies of older workers. Personnel Review, 39(3), 308-324. https://doi.org/I0.II08/0048348I0II0305। I

Freund, A. M., \& Baltes, P. B. (1998). Selection, optimization, and compensation as strategies of life management: Correlations with subjective indicators of successful aging. Psychology and Aging, 13(4), 53 I-543. https://doi.org// 0.1037/0882-7974.I3.4.53 |

Han, S. K., \& Moen, P. (1999). Clocking out: Temporal patterning of retirement. American Journal of Sociology, 105(I), 191-236. https://doi.org//0.1086/21027I

Hansson, R. O., DeKoekkoek, P. D., Neece, W. M., \& Patterson, D. W. (1997). Successful aging at work: Annual review, 1992-1996: The older worker and transitions to retirement. Journal of Vocational Behavior, 5 I (2), 202-233. https://doi.org/I0.1006/jvbe.1997.1605

Herrbach, O., Mignonac, K., Vandenberghe, C., \& Negrini, A. (2009). Perceived HRM practices, organizational commitment, and voluntary early retirement among late-career managers. Human Resource Management, 48(6), 895-9I5. https://doi.org/I0.1002/hrm.2032I

Hess, M. (2017). Rising preferred retirement age in Europe: Are Europe's future pensioners adapting to pension system reforms? Journal of Aging \& Social Policy, 29(3), 245-26I. https://doi.org// 0.1080/08959420.2016.1255082

Hobfoll, S. E. (1989). Conservation of resources: A new attempt at conceptualizing stress. American Psychologist, 44(3), 513-524. https://doi.org/I0.1037//0003-066X.44.3.5 I 3

Hobfoll, S. E., Halbesleben, J., Neveu, J. P., \& Westman, M. (2018). Conservation of resources in the organizational context: The reality of resources and their consequences. Annual Review of Organizational Psychology and Organizational Behavior, 5, 103-128. https://doi.org// 0.1 I46/annurevorgpsych-032117-104640

Hofäcker, D. (20I5). In line or at odds with active ageing policies? Exploring patterns of retirement preferences in Europe. Ageing \& Society, 35(7), I529-I556. https://doi.org/10.1017/S0I44686X1400035X

Ilmarinen, J. E. (200I). Aging workers. Occupational and Environmental Medicine, 58(8), 546-552. https://doi.org// 0.1 I36/oem.58.8.546 
Ilmarinen, J. (2009). Work ability - A comprehensive concept for occupational health research and prevention. Scandinavian Journal of Work, Environment \& Health, 35(I), I-5. https://doi.org/I0.527I/sjweh.I 304

Ilmarinen, J., \& Rantanen, J. (1999). Promotion of work ability during ageing. American Journal of Industrial Medicine, 36(SI), 2I-23. https://doi.org/I0.1002/(SICI) I097-0274(I 99909)36:I +<2 I::AIDAJIM8>3.0.CO;2-S

Ilmarinen, J., \& Tuomi, K. (1992). Work ability of aging workers. Scandinavian Journal of Work, Environment \& Health, I8(2), 8- 10.

Ilmarinen, J., \& von Bonsdorff, M. (2016). Work Ability. In S. K. Whitbourne (Ed.), The encyclopedia of adulthood and aging (Vol. 3, pp. I44I-I445). Hoboken, NJ: John Wiley \& Sons, Inc.

Kanfer, R., \& Ackerman, P. L. (2004). Aging, adult development, and work motivation. Academy of Management Review, 29(3), 440-458. https://doi.org// 0.5465/AMR.2004.13670969

Khilji, S. E., \& Wang, X. (2006). 'Intended' and 'implemented' HRM: The missing linchpin in strategic human resource management research. The International Journal of Human Resource Management, I7(7), II7I-I I89. https://doi.org/I0.1080/09585190600756384

Kim, S., \& Feldman, D. C. (1998). Healthy, wealthy, or wise: Predicting actual acceptances of early retirement incentives at three points in time. Personnel Psychology, 5I(3), 623-642. https://doi.org//0.1 I I I/j.1744-6570.1998.tb00254.x

Kooij, D. T. A. M., Guest, D., Clinton, M., Knight, T., Jansen, P., \& Dikkers, J. (20/3). How the impact of HR practices on employee wellbeing and performance changes with age. Human Resource Management Journal, 23(I), 18-35. https://doi.org/ I 0.I I I/I 748-8583. 12000

Kooij, D. T. A. M., Jansen, P. G. W., Dikkers, J. S. E., \& De Lange, A. H. (20I0). The influence of age on the associations between HR practices and both affective commitment and job satisfaction: A meta-analysis. Journal of Organizational Behavior, 3I(8), IIII-II36. https://doi.org//0.1002/job.666

Kooij, D. T. A. M., Jansen, P. G. W., Dikkers, J. S. E., \& De Lange, A. H. (20/4). Managing aging workers: A mixed methods study on bundles of HR practices for aging workers. The International Journal of Human Resource Management, 25(15), 2192-2212. https://doi.org//0.1080/09585192.2013.872169

Kunze, F., Boehm, S., \& Bruch, H. (20/3). Organizational performance consequences of age diversity: Inspecting the role of diversity-friendly HR policies and top managers' negative age stereotypes. Journal of Management Studies, 50(3), 4I3-442. https://doi.org/ I 0. I I I I/joms. 12016 Lindberg, P., Josephson, M., Alfredsson, L., \& Vingård, E. (2006). Promoting excellent work ability and preventing poor work ability: The same determinants? Results from the Swedish HAKuL 
study. Occupational and Environmental Medicine, 63(2), II3-I20. https://doi.org//0.1 I36/oem.2005.022129

Loretto, W., \& White, P. (2006). Work, more work and retirement: Older workers' perspectives. Social Policy and Society, 5(4), 495-506. https://doi.org/I0.I0 I7/SI474746406003204

McGonagle, A. K., Fisher, G. G., Barnes-Farrell, J. L., \& Grosch, J. W. (20I5). Individual and work factors related to perceived work ability and labor force outcomes. Journal of Applied Psychology, I00(2), 376-398. https://doi.org/10.1037/a0037974

Moen, P. (20I2). Retirement dilemmas and decisions. In J. W. Hedge, \& W. C. Borman (Eds.), The Oxford handbook of work and aging (pp. 549-569). New York: Oxford University Press.

Naegele, G., \& Krämer, K. (2002). Recent developments in the employment and retirement of older workers in Germany. Journal of Aging \& Social Policy, 13(1), 69-92. https://doi.org/I0.1300/J03IvI3n0I_05

Newman, D. A., Jeon, G., \& Hulin, C. L. (2013). Retirement attitudes: Considering etiology, measurement, attitude-behavior relationships, and attitudinal ambivalence. In M. Wang (Ed.), The Oxford handbook of retirement (pp. 228-248). New York: Oxford University Press.

Ng, T. W. H., \& Feldman, D. C. (2008). The relationship of age to ten dimensions of job performance. Journal of Applied Psychology, 93(2), 392-423. https://doi.org//0.1037/00219010.93 .2 .392

Oakman, J., \& Wells, Y. (20/3). Retirement intentions: what is the role of push factors in predicting retirement intentions? Ageing \& Society, 33(6), 988-1008. https://doi.org/I0.10I7/S0 I44686X1200028I

Oksanen, T., \& Virtanen, M. (20I2). Health and retirement: a complex relationship. European Journal of Ageing, 9(3), 22I-225. https://doi.org/ 10.1007/s I 0433-012-0243-7

Pinto, A. M. G. L. R. S., Ramos, S. C. M. S., \& Nunes, S. M. M. D. (2014). Managing an aging workforce: What is the value of human resource management practices for different age groups of workers? Tékhne, 12, 58-68. https://doi.org/I0.1016/j.tekhne.2015.01.007

Posthuma, R. A., \& Campion, M. A. (2009). Age stereotypes in the workplace: Common stereotypes, moderators, and future research directions. Journal of Management, 35(I), I58-I88. https://doi.org/10.1 I77/0149206308318617

Potočnik, K., Tordera, N., \& Peiró, J. M. (2009). The role of human resource practices and group norms in the retirement process. European Psychologist, 14(3), 193-206. https://doi.org//0.1027/1016-9040.14.3.193

Preacher, K. J., \& Hayes, A. F. (2008). Asymptotic and resampling strategies for assessing and comparing indirect effects in multiple mediator models. Behavior Research Methods, 40(3), 87989I. https://doi.org// 0.3758/BRM.40.3.879 
Rabl, T., \& Triana, M. (20I4). Organizational value for age diversity and potential applicants' organizational attraction: Individual attitudes matter. Journal of Business Ethics, I2I(3), 403-4I7. https://doi.org//0.1007/s 1055I-013-1729-8

Radkiewicz, P., \& Widerszal-Bazyl, M. (2005). Psychometric properties of Work Ability Index in the light of comparative survey study. International Congress Series, 1280, 304-309. https://doi.org// 0.1016/j.ics.2005.02.089

Riach, K. (2009). Managing 'difference': Understanding age diversity in practice. Human Resource Management Journal, 19(3), 3 I9-335. https://doi.org/ I0. I I I I/j. I748-8583.2009.00096.x

Saba, T., \& Guerin, G. (2005). Extending employment beyond retirement age: The case of health care managers in Quebec. Public Personnel Management, 34(2), 195-2/4. https://doi.org//0.1 177/009/02600503400205

Salthouse, T. A. (20/2). Consequences of age-related cognitive declines. Annual Review of Psychology, 63, 20I-226. https://10.1 I46/annurev-psych-I 207I0-100328

Schalk, R., Van Veldhoven, M., De Lange, A. H., De Witte, H., Kraus, K., Stamov-Roßnagel, C., ... \& Zacher, H. (2010). Moving European research on work and ageing forward: Overview and agenda. European Journal of Work and Organizational Psychology, 19(1), 76-I0I. https://doi.org// 0.1080//3594320802674629

Sell, L., Bültmann, U., Rugulies, R., Villadsen, E., Faber, A., \& Søgaard, K. (2009). Predicting longterm sickness absence and early retirement pension from self-reported work ability. International Archives of Occupational and Environmental Health, 82(9), II33-II38. https://doi.org//0.1007/s00420-009-0417-6

Shultz, K. S., Morton, K. R., \& Weckerle, J. R. (1998). The influence of push and pull factors on voluntary and involuntary early retirees' retirement decision and adjustment. Journal of Vocational Behavior, 53(I), 45-57. https://doi.org/ 10.1006/jvbe.1997.1610

Shultz, K. S., \& Wang, M. (2007). The influence of specific physical health conditions on retirement decisions. The International Journal of Aging and Human Development, 65(2), 149-161. https://doi.org// 0.2190/AG.65.2.c

Solem P. E., Syse A., Furunes T., Mykletun R. J., De Lange A. H., Schaufeli W. B., \& Ilmarinen J. (2016). To leave or not to leave: Retirement intentions and retirement behaviour. Ageing \& Society, 36(2), 259-28I. https://doi.org/I0.1017/S0 I44686XI400II35

Statistics Portugal. (20I4). Resident population projections - 20I2-2060. Lisbon: Statistics Portugal.

Statistics Portugal. (2015). Aging of the resident population in Portugal and in the European Union. Lisbon: Statistics Portugal.

Stone, D. L., \& Tetrick, L. E. (2013). Understanding and facilitating age diversity in organizations. Journal of Managerial Psychology, 28(7/8), 725-728. https://doi.org/I0.I I08/JMP-07-20 I3-0226 
Streb, C. K., Voelpel, S. C., \& Leibold, M. (2008). Managing the aging workforce: Status quo and implications for the advancement of theory and practice. European Management Journal, 26(I), I10. https://doi.org//0.1016/j.emj.2007.08.004

Szinovacz, M. E., \& Davey, A. (2005). Predictors of perceptions of involuntary retirement. The Gerontologist, 45(I), 36-47. https://doi.org/I0.1093/geront/45.I.36

Szinovacz, M. E., DeViney, S., \& Davey, A. (200I). Influences of family obligations and relationships on retirement variations by gender, race, and marital status. The Journals of Gerontology Series B: Psychological Sciences and Social Sciences, 56(I), S20-S27. https://doi.org/I0.1093/geronb/56.I.S20

Teiger, C. (1989). Le vieillissement différentiel par et dans le travail: un vieux problème dans un contexte récent. Le Travail Humain, 52, 21-56.

Tengland, P. A. (20II). The concept of work ability. Journal of Occupational Rehabilitation, 2 I(2), 275-285. https://doi.org/10.1007/s 10926-010-9269-x

Topa, G., Depolo, M., \& Alcover, C. M. (2018). Early retirement: A meta-analysis of its antecedent and subsequent correlates. Frontiers in Psychology, 8:2157. https://doi.org//0.3389/fpsyg.2017.02157

Topa, G., Moriano, J. A., Depolo, M., Alcover, C. M., \& Morales, J. F. (2009). Antecedents and consequences of retirement planning and decision-making: A meta-analysis and model. Journal of Vocational Behavior, 75(I), 38-55. https://doi.org/I0.1016/j.jvb.2009.03.002

Truxillo, D. M., Cadiz, D. M., \& Hammer, L. B. (20I5). Supporting the aging workforce: A review and recommendations for workplace intervention research. Annual Review of Organizational Psychology and Organizational Behavior, 2, 35I-38I. https://doi.org//0.1/46/annurev-orgpsych0324|4-II| 435

Truxillo, D. M., Cadiz, D. M., \& Rineer, J. R. (2017). The aging workforce: Implications for human resource management research and practice. In M. A. Hitt, S. E. Jackson, S. Carmona, L. Bierman, C. E. Shalley, \& M. Wright (Eds.), The Oxford handbook of strategy implementation (pp. 179-237). New York: Oxford University Press.

Tuomi, K., Huuhtanen, P., Nykyri, E., \& Ilmarinen, J. (200I). Promotion of work ability, the quality of work and retirement. Occupational Medicine, 5I(5), 3I8-324. https://doi.org//0.1093/occmed/51.5.318

Tuomi, K., Ilmarinen, J., Jahkola, A., Katajarinne, L., \& Tulkki, A. (1998). Work ability index (2nd ed.). Helsinki, Finland: Finnish Institute of Occupational Health.

Tuomi, K., Vanhala, S., Nykyri, E., \& Janhonen, M. (2004). Organizational practices, work demands and the well-being of employees: a follow-up study in the metal industry and retail trade. Occupational Medicine, 54(2), I I5-I2I. https://doi.org/I0.1093/occmed/kqh005

United Nations (UN). (20I7). World population ageing. New York: United Nations. 
van Dalen, H. P., Henkens, K., \& Wang, M. (2015). Recharging or retiring older workers? Uncovering the age-based strategies of European employers. The Gerontologist, 55(5), 8I4-824. https://doi.org/10.1093/geront/gnu048

van Solinge, H., \& Henkens, K. (2009). Living longer, working longer? The impact of subjective life expectancy on retirement intentions and behaviour. European Journal of Public Health, 20(I), 475I. https://doi.org/I0.1093/eurpub/ckp I I8

Vendramin, P., Valenduc, G., Volkoff, S., Molinié, A-F., Léonard, E., \& Ajzen, M. (20I2). Sustainable work and the ageing workforce. Luxembourg: Publications Office for the European Union.

Vickerstaff, S., Cox, J., \& Keen, L. (2003). Employers and the management of retirement. Social Policy \& Administration, 37(3), 27 I-287. https://doi.org/ I 0. I I I I/I467-95 I 5.00338

von Bonsdorff, M. E., Huuhtanen, P., Tuomi, K., \& Seitsamo, J. (2010). Predictors of employees' early retirement intentions: An II-year longitudinal study. Occupational Medicine, 60(2), 94-I00. https://doi.org//0.1093/occmed/kqp 126

von Bonsdorff, M. B., Seitsamo, J., Ilmarinen, J., Nygård, C. H., von Bonsdorff, M. E., \& Rantanen, T. (20I I). Work ability in midlife as a predictor of mortality and disability in later life: a 28-year prospective follow-up study. Canadian Medical Association Journal, I83(4), E235-E242. https://doi.org/I0.1503/cmaj. I007/3

Walker, A. (1999). Managing an ageing workforce - A guide to good practice. Luxembourg: Office for Official Publications of the European Communities.

Walker, A. (2005). The emergence of age management in Europe. International Journal of Organisational Behaviour, IO(I), 685-697.

Wegge, J., Jungmann, F., Liebermann, S., Shemla, M., Ries, B. C., Diestel, S., \& Schmidt, K. H. (20I2). What makes age diverse teams effective? Results from a six-year research program. Work, 4I, 5|45-5I5I. https://doi.org//0.3233/WOR-20I2-0084-5I45

Young, L. M., Baltes, B. B., \& Pratt, A. K. (2007). Using selection, optimization, and compensation to reduce job/family stressors: Effective when it matters. Journal of Business and Psychology, 2 I (4), 5I I-539. https://doi.org// 0.1007/s 10869-007-9039-8

Zacher, H. (20I5). Successful aging at work. Work, Aging and Retirement, I(I), 4-25. https://doi.org//0.1093/workar/wau006

Zaniboni, S. (20I5). The interaction between older workers' personal resources and perceived age discrimination affects the desired retirement age and the expected adjustment. Work, Aging and Retirement, I(3), 266-273. https://doi.org/I0.1093/workar/wav0 I

Zappalà, S., Depolo, M., Fraccaroli, F., Guglielmi, D., \& Sarchielli, G. (2008). Postponing job retirement? Psychosocial influences on the preference for early or late retirement. Career Development International, I3(2), I50-I67. https://doi.org/I0.I I08/I36204308 I0860558 